\title{
First Record of The Burrowing Goby Trypuchen vagina from Pangpang Bay, Indonesia
}

\author{
Sapto Andriyono ${ }^{1 *}$, Endang Dewi Masithah ${ }^{1}$, Heru Pramono ${ }^{1}$, Suciyono $^{2}$ \\ ${ }^{1}$ Department of Marine, Faculty of Fisheries and Marine, Universitas Airlangga \\ Campus C UNAIR JI. Mulyorejo, Surabaya, 601 145, Indonesia \\ 2 Aquaculture Study Program, Faculty of Fisheries and Marine, Universitas Airlangga, \\ J. Wijaya Kusuma No 113, Banyuwangi, Indonesia \\ Email: sapto.andriyono@fpk.unair.ac.id
}

\begin{abstract}
The burrowing goby, Trypauchen vagina, is recorded for the first time from the Pangpang Bay of Banyuwangi, Indonesia. Types of fish $T$. vagina is a type that has not published in Indonesia. This fish was caught using trap net in waters Pangpang Bay, which is an essential area in Banyuwangi, East Java. The description of the morphology and fish habitat conditions shows that the region has a diversity of fish resources that need attention. This goby fish has a local name as fish bedhul picek due to the sense of sight on these fish as if it does not work. Eyes covered by skin and socket head section was not found their eyeballs. The body of the specimens is elongate and reddish-pink in fresh specimens in coloration. There is no barbel on the chin. Cycloid scales are present on the whole body except for the head. Muncar people commonly consume T.vagina. This fish has been food sources in several regions but uncommon at several local markets in Indonesia. The T.vagina inhabit at Pangpang Bay as the bay, which has the high primary productivity of these waters due to sufficient nutrient support. Enrichment of nutrient comes from the run-off land and also the input of the number of fishing activity (embankment). An earlier report said that this fish found in waters Banyu Asin, Palembang, Sumatra, Indonesia. It also confirms that the fish found in this study are also living in a mud substrate that is reasonably smooth with right mangrove conditions around the bay, which close to Alas Purwo National Park.
\end{abstract}

Keywords: Trypauchen vagina, Pangpang Bay, goby, essential area

\section{Introduction}

Pangpang bay region is administratively located in the district of Banyuwangi (Kawamuna et al., 2017) adjacent to the Bali Strait and the Indian Ocean. There is a massive potential in this region include the potential for capture fisheries, fish processing, aquaculture, and the existence of mangrove ecosystems. However, the pattern of resource use that is not appropriately managed it causes environmental problems to include a decline in water quality due to the disposal of organic waste fishery without treatment, the status of the excess catch in fisheries sardines, deforestation of mangrove forests for land ponds or activity of urban development, production ponds decline, and abrasion.

The central government conducts a study to establish several areas into regional development fishery products or better known as minapolian. Through the Minister of Marine and Fisheries No.32/MEN/2010, Muncar Banyuwangi, serve as one of the locations, minapolitan fishing is the most potential with consideration some essential aspects. Before 2010, Muncar people have been relying on the resources of fish that has developed since the mid-'60s. It can be seen from numerous research exploring Muncar region associated with the use of traditional fishing technology. In the development of purse-seine introduced by the Marine Fisheries Research Institute (LEDA) in 1972 and continues to use today.

Another potential fish resources in this essential area is a shallow sea fish caught using traditional instruments by local fisherman. One of the fish commonly caught is Bedul picek (local name) which include goby fish group. The IndoPacific gobiid Trypauchenopsis intermedia has reported by Volz (1903) on the waters of the island of Sumatra, Indonesia. This fish previously referred to as Brachyamblyopus intermedius (Eschmeyer, 2009). This fish species rarely found, and only one specimen is accidentally caught on scop-net (Bucol et al., 2012). The purpose of this study was to document the burrowing goby fish characters from the anatomy of fish and expected to get attention for conservation efforts with the most appropriate strategy.

\section{Materials and Methods}

The study site and sampling locations in the bay of Pangpang, Muncar subdistrict, Banyuwangi is 
shown in Figure 1. Before the survey, coordination with the local community was done. This activity is vital since besides knowing the character of the location, the initial information can be gathered from interviews with local fisherman. Fishing gear used is called Banjang traditional traps (trap net).

Samples were collected every month for three months i.e., March, April, and May. After sampling, the fishes were put in a cool box to avoid spoilage. Samples then were preserved and fixed in alcohol 70\% and 4\% buffered formalin(Syahailatua and Pradina, 1996). Water quality parameters i.e.nitrate, nitrite, phosphate, salinity, dissolved oxygen, and $\mathrm{pH}$ were also measured during the survey. Identification of the fish was made based on a guide book of FAO Species Identification Guide for Fishery Purposes 2001.

\section{Results and Discussion}

This goby fish has a local name as fish bedhul picek due to the sense of sight on these fish as if it does not work. Eye socket head section is not found their eyeballs. The body of the specimens is elongate. The body color is reddish pink in fresh specimens (Figure 2.) and purple in fixed specimens (Akamca et al., 2011). Dorsal and anal fins connected to the caudal fin. There are two dorsal fins, although both of them seem single due to a membranous connecting structure. Pelvic fins are small and fully united, forming a funnel-like disc. An oval-shaped opening (pouchlike cavity) is present at the dorsal margin of the operculum. Caninoid teeth are visible on both of the jaws than eyes covered by skin. There is no barbel on the chin. Cycloid scales are present on the whole body except for the head (Figure 2.). The fish that are quite similar also found in Philippine waters that are geographically close to the territory of Indonesia called the goby fish Trypauchenopsis intermedia (Bucol et al., 2012). An earlier report said that this fish found in waters Banyu Asin, Palembang, Sumatra, Indonesia. It also confirms that the fish found in this study are also living in a mud substrate that is relatively smooth with mangrove conditions around the bay were good.

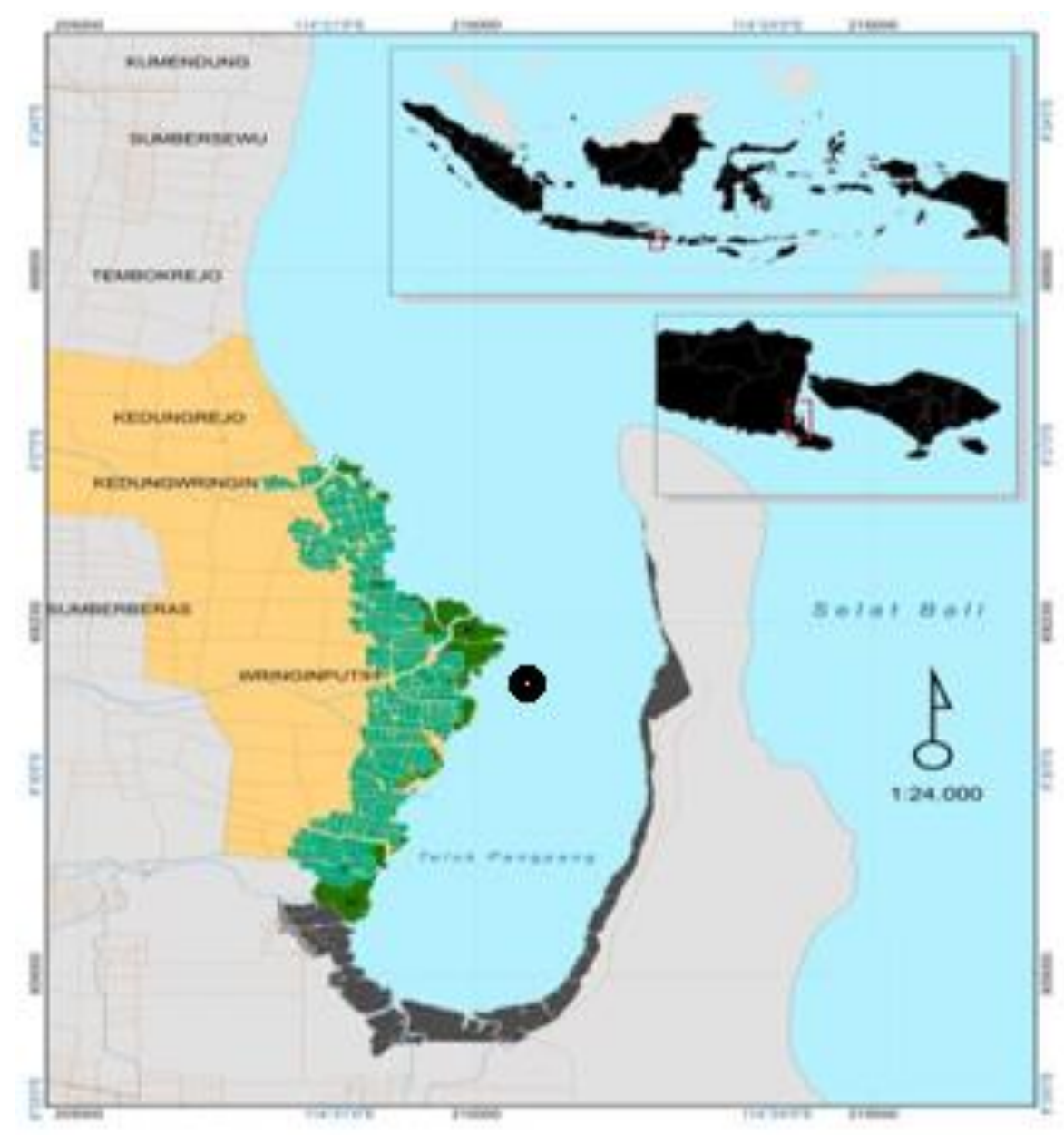

Figure 1. Sampling site at Pangpang Bay, Banyuwangi 


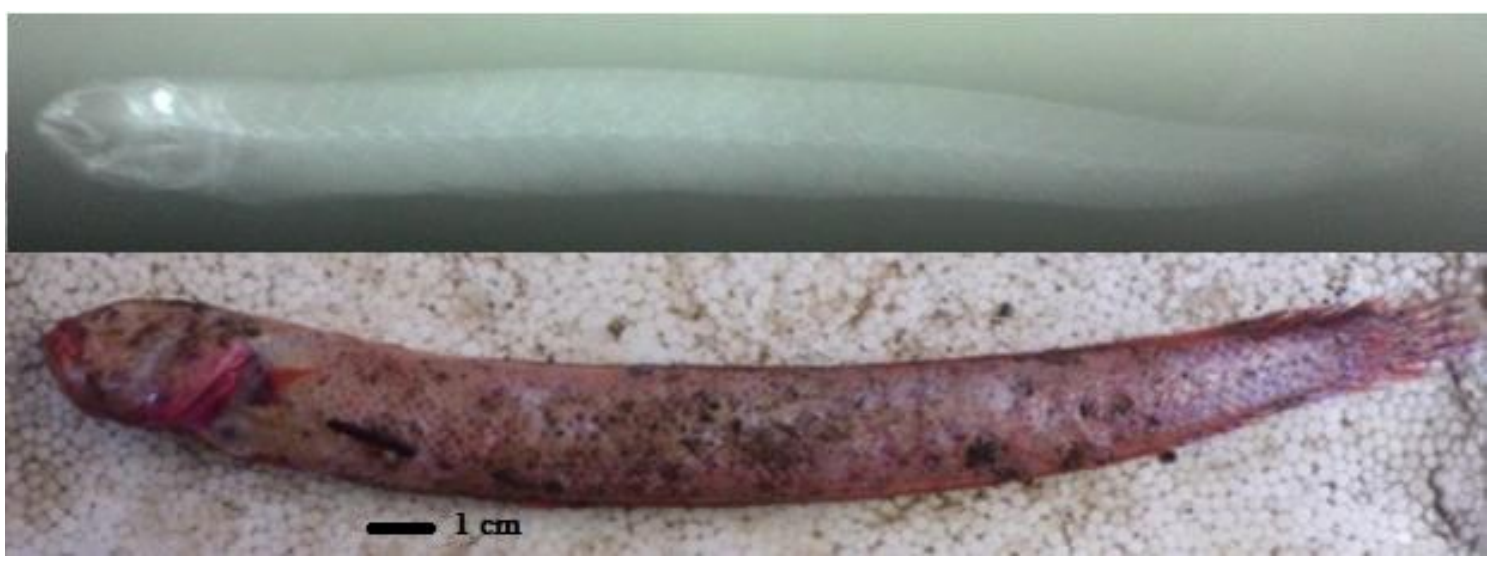

Figure 2. Fish (Trypauchen vagina) appears laterally after radiography photos and shortly after being captured before preservation.

\section{Morphology}

During the survey from March to May 2016, the fish caught only March. Traditionally fishing method was done by using banjang (local name)/scop-net for trap net that relies on the tide. At the time of low tide, the gear will entangle fish that fall into the trap net. This fishing method is passive fishing gear and non-selective fishing gear marked with variable sizes, and types of fish caught. The description of $T$. vagina caught is none based on morphometric measurement parameters are presented in Table 1.

T.vagina is commonly consumed by people Muncar, especially for Wringin-Putih village peoples. This fish has been food sources in several regions (Rainboth, 1996). Fish Trypauchen vagina also first discovered in Turkey and are minimal studies conducted (Alavi-Yeganeh, 2015). However, based on several studies that have been done, it was stated that the species has a wide distribution but uneven Indo-Pacific, from South Africa, Indonesia, China and the Ryukyu Islands Japan (Kottelat et al., 1993). Especially for $T$. vagina species have been found in India (Hora, 1924), Thailand (Smith, 1945), Singapore (Larson and Lim, 2005), the Mekong River (Rainboth, 1996), a number of areas in Indonesia (Kottelat et al., 1993), China (Herre, 1927); and Taiwan (Chen and Fang, 1999).

\section{Pangpang Bay waters condition}

The primary productivity of Pangpang Bay very few studies. These waters have sufficient nutrient support comes from the run-off land by rivers flow and also the input of the number of fishing activity (embankment). The average water quality ever conducted testing found that the levels of ammonia, nitrite, nitrate, and total $\mathrm{N}$ in the intensive pond is higher than the extensive pond (Rasidi et al., 2013). Intensive ponds scattered in the region have contributed some particular elements of Nitrogen derived from the provision of commercial feed. Feed dominate the next most considerable Nitrogen input followed by the inlet (inflow), fertilizer, media probiotics, and fry. The source of Nitrogen in the two types of ponds can derive from fertilization, shrimp ponds, and phytoplankton die in bottom waters. The results of measurements of water quality parameters in the Bay Pangpang presented in Table 2.

Nitrate levels of more than 2.80 mg.L-1 may result in eutrophication that stimulates the growth of phytoplankton rapidly (blooming) (Effendi, 2003) while Susana (2005) set the nitrate levels are suitable for marine life is 5.908 mg.L-1. The concentration of nitrate in the Pangpang bay was between 0.02-0.007 mg.L-1, which indicates as fertile waters. While the phosphate parameters, the entire station showed immeasurable value in the range of 0.04-1.56 mg.L-1. Classification fertility waters in terms of phosphate concentration according to the EPA (2002) in Simanjuntak (2012) states that the value of phosphate is less than 1.55

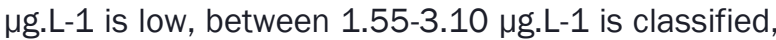
and more than $3.10 \mu g . L-1$ is high. As for the parameters of dissolved oxygen in a body of water, the Environment Ministry set a quality standard that is 0,008 mg.L-1 (KMNLH, 2004). Conditions in the Pangpang Bay is kept stirred waters both from rivers and the sea so that the dissolved oxygen values ranged from 6.2 mg.L-1 around the mouth (mud substrate) and $12.2 \mathrm{mg} . \mathrm{L}-1$ in the region of the mouth bay that leads directly into the Indian Ocean.

Studies that fish in the waters of the Bay of Pangpang highly dependent on their natural food (phytoplankton and zooplankton) evidenced by 
Table 1. Comparison of 13 morphometric characters of one specimens of Trypauchen sp.collected from Pangpang of with those in Murdy (2006) and Bocul et al., (2012)

\begin{tabular}{clcccc}
\hline No. & $\begin{array}{c}\text { Morphometric } \\
\text { characters }\end{array}$ & This Study $(\mathrm{cm})$ & $\begin{array}{c}\text { Murdy, 2006 } \\
\text { (T. vagina) }\end{array}$ & $\begin{array}{c}\text { Murdy, 2006 } \\
\text { (T. pelaeos) }\end{array}$ & $\begin{array}{c}\text { Bocul et al., 2012 } \\
\text { (Trypauchenopsis intermedia) }\end{array}$ \\
\hline 1 & Standard Lengh & 20,5 & 0,855 & 0,824 & 54,5 \\
2 & Head Lengh & 3,40 & 0,169 & 0,201 & 6,00 \\
3 & Pelvic-fin Lengh & 1,00 & 0,060 & 0,072 & - \\
4 & Pectoral-fin Lengh & 1,40 & 0,921 & 0,960 & - \\
5 & Head Width & 2,25 & 0,084 & 0,091 & 4,00 \\
6 & Snout Lengh & 0,80 & 0,048 & 0,039 & 1,50 \\
7 & Interorbital Width & 1,00 & 0,027 & 0,033 & 1,00 \\
8 & Jaw Lengh & 1,00 & 0,050 & 0,061 & - \\
9 & Nape Width & 0,80 & 0,064 & 0,067 & - \\
10 & Body Depth & 2,40 & 0,107 & 0,119 & - \\
11 & Pre-dorsal Lengh & 4,00 & 0,202 & 0,238 & - \\
12 & Pre-pelvic Lengh & 3,00 & 0,165 & 0,195 & 18,5 \\
13 & Pre-anal Lengh & 6,40 & 0,345 & 0,390 & - \\
\hline
\end{tabular}

Table2.The results of in-situ measurements of physical-chemical parameters of Pangpang Bay waters

\begin{tabular}{clcc}
\hline No. & Parameters & Units & Mean \\
\hline 1 & DO & $\mathrm{mg} . \mathrm{L}^{-1}$ & $6.20-12.2$ \\
2 & Salinity & $\mathrm{ppt}$ & $19.0-34.00$ \\
3 & $\mathrm{pH}$ & & $6.50-7.500$ \\
4 & Nitrate & $\mathrm{mg} \cdot \mathrm{L}^{-1}$ & $0.02-0.07$ \\
5 & Nitrite & $\mathrm{mg} \cdot \mathrm{L}^{-1}$ & $0.02-0.12$ \\
6 & Phospate & $\mathrm{mg} \cdot \mathrm{L}^{-1}$ & $0.04-1.56$ \\
7 & Brightness & $\mathrm{m}$ & $30-100$ \\
8 & Depth & $\mathrm{m}$ & $1-10$ \\
9 & Temperature & ${ }^{\circ} \mathrm{C}$ & $31-32$ \\
\hline
\end{tabular}

studies of Sardines stomach contents. Test results showed that the Sardines stomach contents classified as plankton feeder. The food can be divided into two categories, are zooplankton and phytoplankton. Zooplankton occupied the highest percentage in the range of 90.52 to $95.45 \%$; the percentage of phytoplankton only ranged from 4.469.48\% (Dhulked, 1962). Sardines is a phytoplankton feeder, especially Bacrllariphyceae group (Pradiniet al., 2001).

\section{Conclusion}

The existence burrowing goby ( $T$. vagina) in this area indicates that the fish can adapt and breed in these areas. This fish possible as bio-indicator of a healthy habitat. However, the pressure from traditional fisheries needs to get attention and support in preserving fish resources of Pangpang Bay.

\section{References}

Akamca, E.,Mavruk, S., Ozyurt, C.E.\& Kiyaga, V.B. 2011. First Record of The Indo-Pacific Burrowing Goby Trypauchen Vagina (Bloch AndSchneider, 1801) in The North-Eastern Mediterranean Sea. Aquatic Invasions, 6(Supp 1): S19-S21. doi: 10.3391/ai.2011.6.S1.004

Alavi-Yeganeh, M.S., Deyrestani, A.,\&Murdy, E.O. 2015. First Record of The Burrowing Goby, Trypauchen vagina (Actinopterygii: Gobiidae), From The Iranian Coast of The Persian Gulf. Turk. J. Zool., 39: 717-720. doi:10.3906/zoo1404-12

Bucol, A.A., Alcala, E.L. \& Alcala, A.C. 2001. The Goby Trypauchenopsis Intermedia Volz 1903(Gobiidae) From The Philippines. Philipp. Scient. 49: 97-101. 
Chen, I.S. \& Fang, L.S. 1999.The Freshwater and Estuarine Fishes of Taiwan, NationalMuseum of Marine Biology \& Aquarium, Pingtung, 287 pp.

Dhulked, M.H. 1962. Observation on the food and feeding habits ofthe indian oil sardine, Sardinella longiceps (Valenciennes).Indian J. Fish. 9(I): 37- a7

Effendi, H. 2003. Telaah kualitas air bagi pengelolaan sumberdaya dan lingkungan perairan. Penerbit Kanisius, Jogyakarta.

Environmental Protection Agency (EPA). 2002. Water Quality Criteria. Mid-Atlantic Integrated Assessment (MAIA) Estuaries. USA. Ecological Research Series Washington. 595p.

Eschmeyer W. 2009. Catalog of Fishes. California Academy of Sciences.ww.calacademy.org

FAO, 1999. The Living Marine Resources of the Western Central Pacific. Food and Agriculture Organization of the United Nations. Rome.

Herre, A.W.C.T. 1927. Gobies of the Philippines and the China Sea. Monograph of the Bureau ofScience, Manila, 23: 352 pp.

Hora, S.L. 1924. Notes on fishes in the Indian Museum. VI. On a new genus of gobioid fishes(subfamily Trypaucheninae) with notes on related forms. Records of the Indian Museum, Calcutta,26: 155-163.

Kawamuna, A., Suprayogi, A. \& Wijaya, A.P., 2017. Analisis Kesehatan Hutan Mangrove Berdasarkan Metode Klasifikasi Ndvi Pada Citra Sentinel-2 (Studi Kasus: Teluk Pangpang Kabupaten Banyuwangi). J. Geodesi Undip,6(1): 277-284.

KMNLH, 2004. Keputusan Kantor Menteri Negara Kependudukan dan Lingkungan Hidup No. 51Tahun 2004. Tentang baku mutu air laut. Kantor Menteri Negara Lingkungan Hidup. Jakarta.
Kottelat, M., Whitten, A.J., Kartikasari, S.N.\& Wirjoatmodjo, S. 1993.) Freshwater Fishes ofWestern Indonesia and Sulawesi. Wildlife Heritage Trust of Sri Lanka, Colombo, 259 pp.

Larson, H.K. \& Lim, K.K.P. 2005.A Guide to Gobies of Singapore. Singapore Science Centre, $164 p p$.

Murdy, E.O. 2006. A Revision Of The Gobiid Fish Genus Trypauchen(Gobiidae: Amblyopinae). Zootaxa 1343: 55-68.

Pradini, S.,Rahardjo, M.F.\& Kaswadji, R. Kebiasaan Makanan Ikan Lemuru (Sardinella lemuru) di Perairan Muncar, Banyuwangi. J. Iktiologi Indonesia.1(1): 41-45.

Rainboth, W.J. 1996.FAO species identification field guide for fishery purposes. Fishes of theCambodian Mekong. Rome, FAO. 1-265, PIs. I-XXVII.

Rasidi, Brata, P., I Nyoman, R., \& Idil, A., 2013. Kondisi Lingkungan di Kawasan Pertambakan Kabupaten Banyuwangi, Jawa Timur dan Strategi Pengelolaan Lingkungan Budidayanya. Pros. Forum Inovasi Teknologi Akuakultur. 1(1): 1123-1134.

Simanjuntak, M. 2012. Kualitas Air Laut Ditinjau Dari Aspek Zat Hara, Oksigen Terlarut dan pH Di Perairan Banggai, Sulawesi Tengah.J. IImu dan Teknol. Kelautan Tropis, 4(2): 290-303.

Smith, H.M. 1945. The fresh-water fishes of Siam, or Thailand. Bulletin of the U. S. NationalMuseum, 188: 1-622.

Susana, T. 2005. Kualitas zat hara perairan Teluk Lada, Banten. Oseanologi dan Limnologi di Indonesia, 37: 59-67.

Volz, W. 1903. Neue Fische aus Sumatra. Zoologischer Anzeiger, 26(703): 553-559. 